\title{
ACO2 mutations: A novel phenotype associating severe optic atrophy and spastic paraplegia
}

Cecilia Marelli, MD, PhD, Christian Hamel, MD, PhD, † Melanie Quiles, Tech, Bertrand Carlander, MD, Lise Larrieu, Tech, Cecile Delettre, PhD, Emmanuelle Sarzi, PhD, Dominique Chretien, PhD, Pierre Rustin, PhD, Michel Koenig, MD, PhD, and Claire Guissart, PharmD, PhD

Neurol Genet 2018;4:e225. doi:10.1212/NXG.0000000000000225

Aconitase 2 (ACO2) encodes the mitochondrial aconitase (ACO2), an enzyme catalyzing interconversion of citrate into isocitrate in the Krebs cycle. ACO2 mutations have been initially associated with infantile cerebellar-retinal degeneration combining optic atrophy, retinal degeneration, severe encephalopathy, epilepsy, and cerebellar ataxia ${ }^{1-3}$; subsequently, ACO2 mutations have also been associated with milder presentations including isolated optic atrophy ${ }^{2}$ or cerebellar ataxia without optic atrophy. ${ }^{4}$ We report here a patient presenting with a novel ACO2 phenotype associating optic atrophy with spastic paraplegia.

\section{Methods}

Mini-exome sequencing by exon capture (TruSight One Sequencing Panel kit-Montpellier NGS platform) was performed in a patient with familial syndromic optic atrophy. Written informed consent was obtained. Aconitase enzymatic activity was measured as previously described. ${ }^{5}$

\section{Case report}

A now 56-year-old white lady issued from a nonconsanguineous union presented because of severe optic atrophy and spastic paraplegia. Her symptoms had been slowly progressive since infancy and associated with delayed motor (walking at about 3 years) and mental development. An ophthalmologist (C.H.) first examined her at the age of 38 years because of her visual problems. She came to the neurologic clinic at the age of 49 years because of aggravation of the spastic paraplegia, requiring a walking aid. She currently presents with mild cognitive involvement allowing a relatively autonomous life with a sheltered social work. Her sister (not directly examined) has a similar but more severe clinical presentation with visual problems, spasticity, and mental retardation. Cerebral MRI showed mild vermian cerebellar atrophy and nonspecific $\mathrm{T} 2$ and fluid-attenuated inversion recovery hyperintensities in cerebellar dentate nuclei and supratentorial white matter (figure, A-D). Neurologic examination revealed severe visual impairment, mild upper limb ataxia, diffuse hyperreflexia, and severe spastic paraplegia with bilateral extensor plantar reflex. Ophthalmological evaluation confirmed the presence of bilateral optic atrophy without retinal involvement, globally stable since first examination at the age of 38 years. Visual acuity was severely reduced (right eye: counts the fingers at $30 \mathrm{~cm}$; left eye: counts the fingers at $1 \mathrm{~m}$ ). The patient did not present any signs of peripheral neuropathy, and the EMG was normal. Mini-exome analysis identified compound heterozygous mutations in the ACO2 gene (c.2135C>T [p.(Pro712Leu) $]^{4}$; c.940+5G>C) in the patient and her

\author{
Correspondence \\ Dr. Guissart \\ claire.guissart@inserm.fr
}




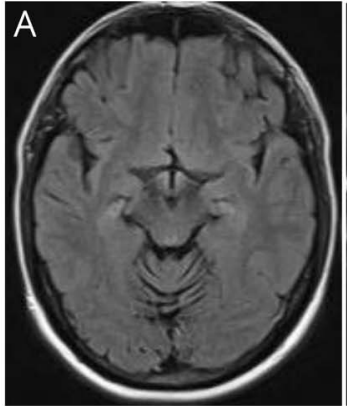

E $\quad \mathrm{P} 712 \mathrm{~L} / \mathrm{N}$

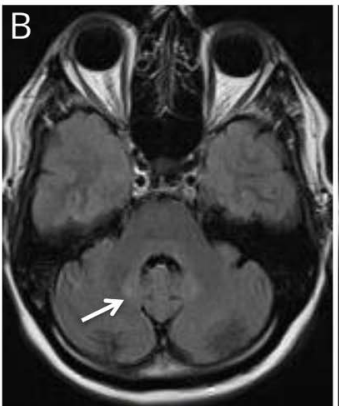

$\mathrm{F}$
$1-2$

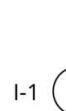
c. $940+5 \mathrm{G}>\mathrm{C} / \mathrm{N}$

\section{II-4}

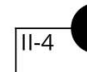
c. $940+5 G>C / P 712 L$<smiles>C=C1CCCC1</smiles>
C. $940+5 G>C / P 712 L$

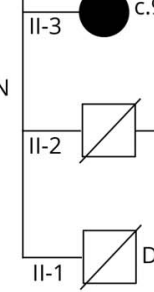

$\mathrm{H}$

c. $940+5 G>C$

I AAGgtgagctggca

$-1$

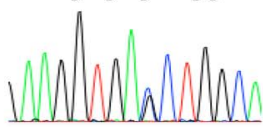

$1-2$

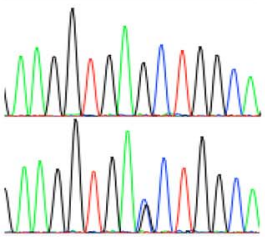

$\|-1$

II-2

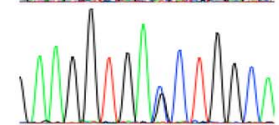

Exon 7 Intron 7
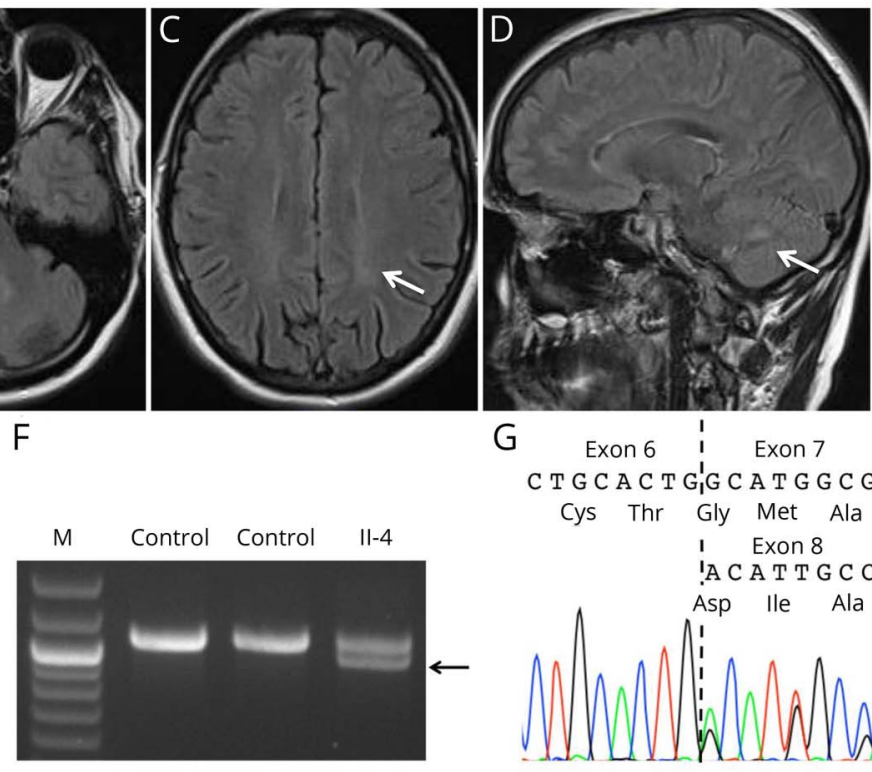

G

Exon $6: 1$ Exon 7 C T G C A C T G'G C A T G G C G

Cys Thr Gly Met Ala I Exon 8 IA C A T T G C C

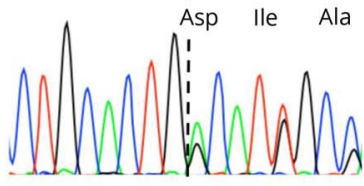

J

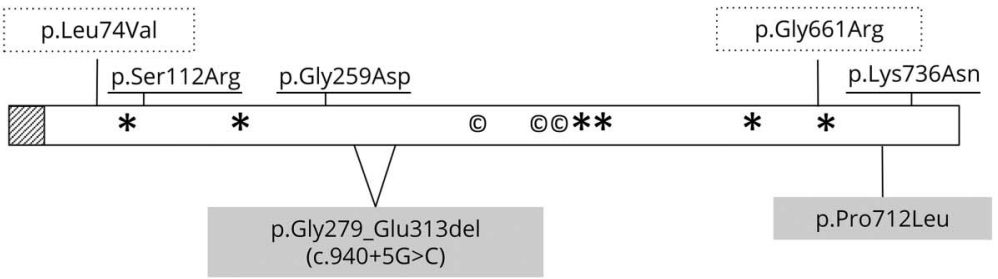

Mild vermian cerebellar atrophy (A, axial FLAIR w.i.); bilateral dentate hyperintensities (white arrow in B, axial FLAIR w.i., and D, sagittal FLAIR w.i); and supratentorial white matter hyperintensities (white arrow in C, axial FLAIR w.i). (E) Pedigree showing segregation of the disease with mutation c.940+5G>C causing the in-frame skipping of exon 7 and with mutation C.2135C $>$ T causing the p.(Pro712Leu) missense change (P712L). Analysis of reverse transcription PCR (RT-PCR) products of the patient skin fibroblasts (F): the c.940+5G $>$ C mutation (SplicePort score reduction from 1.17 to 0.21 ) affects exon 7 splicing and results in an abnormal RT-PCR fragment of $980 \mathrm{bp}$ (arrow), whereas only the normal product of 1,085 bp is seen for control fibroblasts. Sequence of RT-PCR products (G): skipping of exon 7 leading to an in-frame deletion of 35 amino acids (p.[Gly279_Glu313del]). (H) Sanger sequencing results of parents and patients: Both patients are compound heterozygous for the mutations c.940+5G>C and p.(Pro712Leu), the mother (I.1) is a heterozygous carrier for the c.940+ $5 \mathrm{G}>\mathrm{C}$ mutation, and the father (I.2) is a heterozygous carrier for the p.(Pro712Leu) mutation. (I) Mitochondrial aconitase activity is measured for 10 minutes (citrate injection), followed by isocitrate dehydrogenase activity for 2 minutes (isocitrate injection) through NADPH production in fibroblasts. Patient II.4 aconitase activity (red line) is reduced to about $50 \%$ of controls (black line), whereas isocitrate dehydrogenase activity, used for normalization, is similar to controls. (J): Predicted location of mutations on the ACO2 enzyme and substrate and cofactor binding sites. Stripe box: mitochondrial targeting signal; *Substrate binding sites; CIron-sulfur binding sites; highlighted mutations: present report; boxed (dotted) mutations: optic atrophy 9 (OPA9) phenotype; underlined mutations: infantile cerebellar-retinal degeneration phenotype (ICRD). FLAIR = fluid-attenuated inversion recovery. 
affected sister (figure, E-H); the second mutation involves exon 7 donor splice site and causes the in-frame skipping of exon 7, as confirmed by reverse transcription PCR (RT-PCR) analysis on patient's skin fibroblasts (figure, $F$ and $G$ ). No relevant variants were found in other genes causing isolated or syndromic optic atrophy. Total aconitase enzymatic activity on the patient's cultured skin fibroblasts showed a 50\% decrease in activity in the presence of citrate and a $40 \%$ decrease in activity in the presence of cis-aconitate (compared with isocitrate dehydrogenase activity as a reference) (figure, I), suggesting, in the presence of the two ACO2 mutations, ACO2 impairment. We did not find mt-DNA depletion in the patient's fibroblasts and leukocytes (not shown).

\section{Discussion}

In this report, we expand the phenotype of $A C O 2$ mutations describing a patient with severe spastic paraplegia and symptomatic optic atrophy; the patient also had a relatively mild cognitive involvement, while cerebellar involvement, usually associated with $A C O 2$ mutations, ${ }^{1-4}$ was clinically very mild, although present at the imaging level.

The pathogenicity of the mutations was confirmed by the segregation in the family and by the quantification of the enzymatic activity, consistent with deficiencies observed in previously reported milder ACO2 cases. $^{2}$ Moreover, the pathogenicity of the intronic mutation was confirmed by RT-PCR studies.

The presently described phenotype might evoke a spastic paraplegia, optic atrophy, and peripheral neuropathy-like phenotype ${ }^{6}$ but differs because of absent peripheral neuropathy.

Mutations in genes coding for enzymes of the Krebs cycle are globally rare and are often responsible for a large spectrum of disease ranging from severe early-onset encephalopathy to various types of tumors. ${ }^{7}$ The pathophysiologic mechanism could be disruption of energy metabolism and oxidative phosphorylation, but defects in mitochondrial DNA maintenance have also been identified, notably for $\mathrm{ACO}^{4}$ and SUCLA2. ${ }^{8}$

Ocular phenotypes have already been reported in ACO2 deficiency, with optic atrophy and retinal dystrophy, ${ }^{1}$ but also in isocitrate dehydrogenase deficiency, with pigmentary retinopathy, succinyl-CoA synthetase deficiency, with ophthalmoplegia, and succinate dehydrogenase deficiency $(\mathrm{SDH})$, with optic atrophy and pigmentary retinopathy.

Slowly progressive spastic paraplegia has never been reported in ACO2 or in other Krebs cycle defects. Moreover, patients with Krebs cycle defect and isolated organ-specific involvement or milder survival into adulthood are rare and were described for SDH, succinyl-CoA synthetase deficiency (SUCLA2), and fumarase deficiency. The presently reported patient underscores striking variable clinical presentations resulting from ACO2 mutations, ranging from early-onset severe epileptic encephalopathy with cerebello-ocular syndrome (ICRD $)^{1}$ to isolated optic atrophy (OPA9), ${ }^{2}$ complex ataxia without optic atrophy, ${ }^{4}$ and now spastic paraplegia and optic atrophy with survival into adulthood (figure, J). The detection of these milder and new phenotypes is possible because of next-generation sequencing techniques. Milder phenotypes are generally associated, as this is the case of our patient, with moderate residual ACO2 enzymatic activity ${ }^{2}$; however, a case of a relatively mild phenotype despite marked ACO2 enzymatic activity reduction has already been reported, suggesting complex genotype-phenotype correlations. ${ }^{4}$

In addition to severe encephalopathic and cerebello-ocular phenotypes, ACO2 mutations should be investigated in the presence of milder phenotype with slowly progressive spastic paraplegia and optic atrophy.

\section{Author contributions}

Cecilia Marelli: writing of the manuscript, design and conceptualization of the study, analysis and interpretation of the data, study supervision, and critical revision of the manuscript for intellectual concept. Christian Hamel: design and conceptualization of the study, analysis and interpretation of the data, and study supervision. Melanie Quiles, Bertrand Carlander, Lise Larrieu, Cecile Delettre, Emmanuelle Sarzi, Dominique Chretien, and Pierre Rustin: analysis and interpretation of the data and critical revision of the manuscript for intellectual concept. Claire Guissart and Michel Koenig: analysis and interpretation of the data, critical revision of the manuscript for intellectual concept, and study supervision.

\section{Acknowledgment}

This article is dedicated to the memory of Pr Christian Hamel, who died prematurely on August 15, 2017.

\section{Study funding}

No targeted funding reported.

\section{Disclosure}

C. Marelli and M. Quiles report no disclosures. B. Carlander has received travel funding from Biogen. L. Larrieu, C. Delettre, E. Sarzi, D. Chretien, and P. Rustin report no disclosures. M. Koenig has received research support from the Agence Nationale pour la Recherche (ANR)-Maladies Rares and Maladies Neurologiques et Psychiatriques (ANR-09-MNPS-001-01) and the ANR/E-rare JTC 2011 "Euro-SCAR" (2011-RARE-00401). C. Guissart reports no disclosures. Full disclosure form information provided by the authors is available with the full text of this article at Neurology.org/NG.

Received August 27, 2017. Accepted in final form February 1, 2018.

\section{References}

1. Spiegel R, Pines O, Ta-Shma A, et al. Infantile cerebellar-retinal degeneration associated with a mutation in mitochondrial aconitase, ACO2. Am J Hum Genet 2012;90: $518-523$. 
2. Metodiev MD, Gerber S, Hubert L, et al. Mutations in the tricarboxylic acid cycle enzyme, aconitase 2, cause either isolated or syndromic optic neuropathy with encephalopathy and cerebellar atrophy. J Med Genet 2014;51:834-838.

3. Srivastava S, Gubbels CS, Dies $\mathrm{K}$, et al. Increased survival and partly preserved cognition in a patient with ACO2-related disease secondary to a novel variant. J Child Neurol 2017;32:840-845.

4. Sadat R, Barca E, Masand R, et al. Functional cellular analyses reveal energy metabolism defect and mitochondrial DNA depletion in a case of mitochondrial aconitase deficiency. Mol Genet Metab 2016;118:28-34.
5. Goncalves S, Paupe V, Dassa EP, et al. Rapid determination of tricarboxylic acid cycle enzyme activities in biological samples. BMC Biochem 2010;11:5.

6. Lossos A, Stümpfig C, Stevanin G, et al. Fe/S protein assembly gene IBA57 mutation causes hereditary spastic paraplegia. Neurology 2015;84:659-667.

7. Munnich A. Casting an eye on the Krebs cycle. Nat Genet 2008;40: 1148-1149.

8. Ostergaard E, Christensen E, Kristensen E, et al. Deficiency of the alpha subunit of succinate-coenzyme A ligase causes fatal infantile lactic acidosis with mitochondrial DNA depletion. Am J Hum Genet 2007;81:383-387. 


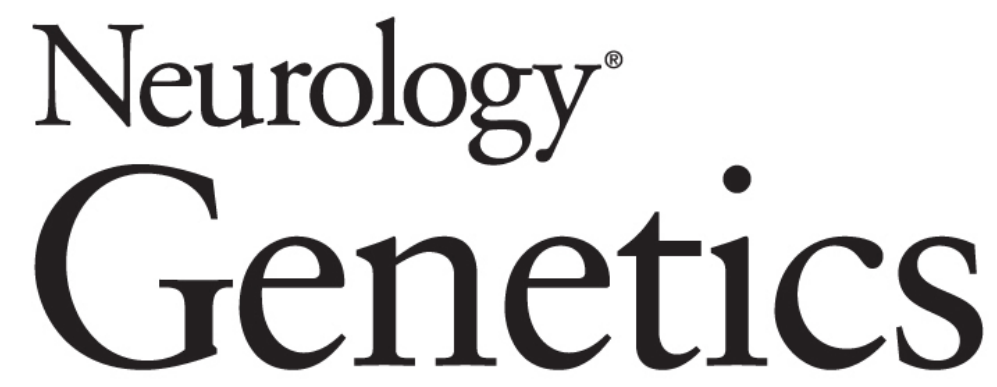

ACO2 mutations: A novel phenotype associating severe optic atrophy and spastic paraplegia

Cecilia Marelli, Christian Hamel, Melanie Quiles, et al.

Neurol Genet 2018;4;

DOI 10.1212/NXG.0000000000000225

This information is current as of March 20, 2018

Neurol Genet is an official journal of the American Academy of Neurology. Published since April 2015, it is an open-access, online-only, continuous publication journal. Copyright Copyright ( 2018 The Author(s).

Published by Wolters Kluwer Health, Inc. on behalf of the American Academy of Neurology. All rights reserved. Online ISSN: 2376-7839.

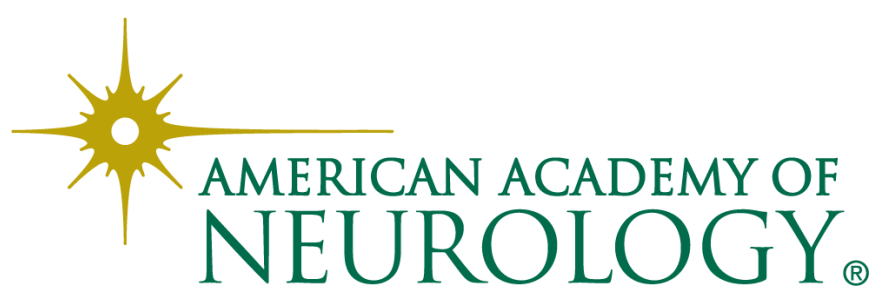




\section{Updated Information \& Services}

References

Subspecialty Collections

Permissions \& Licensing

\section{Reprints}

including high resolution figures, can be found at: http://ng.neurology.org/content/4/2/e225.full.html

This article cites 8 articles, 1 of which you can access for free at: http://ng.neurology.org/content/4/2/e225.full.html\#\#ref-list-1

This article, along with others on similar topics, appears in the following collection(s):

Gait disorders/ataxia

http://ng.neurology.org//cgi/collection/gait_disorders_ataxia

Mitochondrial disorders

http://ng.neurology.org//cgi/collection/mitochondrial_disorders

Optic nerve

http://ng.neurology.org//cgi/collection/optic_nerve

Spastic paraplegia

http://ng.neurology.org//cgi/collection/spastic_paraplegia

Visual loss

http://ng.neurology.org//cgi/collection/visual_loss

Information about reproducing this article in parts (figures,tables) or in its entirety can be found online at:

http://ng.neurology.org/misc/about.xhtml\#permissions

Information about ordering reprints can be found online:

http://ng.neurology.org/misc/addir.xhtml\#reprintsus

Neurol Genet is an official journal of the American Academy of Neurology. Published since April 2015, it is an open-access, online-only, continuous publication journal. Copyright Copyright @ 2018 The Author(s). Published by Wolters Kluwer Health, Inc. on behalf of the American Academy of Neurology. All rights reserved. Online ISSN: 2376-7839.

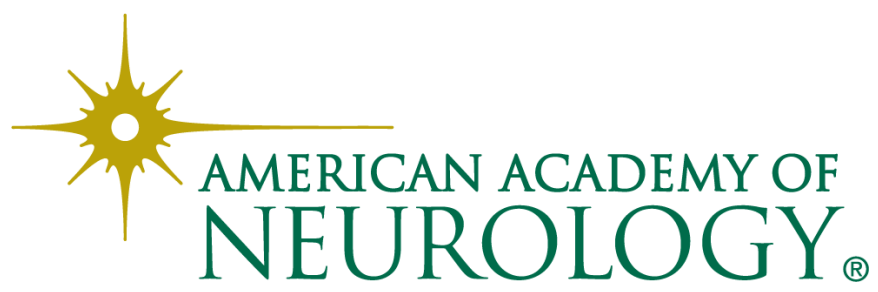

